\title{
GPHN wt Allele
}

National Cancer Institute

\section{Source}

National Cancer Institute. GPHN wt Allele. NCI Thesaurus. Code C97526.

Human GPHN wild-type allele is located in the vicinity of $14 q 23.3$ and is approximately $674 \mathrm{~kb}$ in length. This allele, which encodes gephyrin protein, plays a role in both proteincytoskeleton interactions and biosynthesis of the molybdenum cofactor. Mutation of the gene is associated with both molybdenum cofactor deficiency type $\mathrm{C}$ and startle disease. A chromosomal translocation $\mathrm{t}(11 ; 14)(\mathrm{q} 23 ; \mathrm{q} 23)$ of this gene and the MLL gene is involved in acute myeloid leukemia. 